\title{
The D Allele of the Angiotensin-Converting Enzyme Insertion/ Deletion (I/D) Polymorphism is a Risk Factor for Type 2 Diabetes in a Population-Based Japanese Sample
}

\author{
MAKOTO DAIMON, TOSHIHIDE OIZUMI, TAMOTSU SAITOH, WATARU KAMEDA, \\ AKIHIKO HIRATA*, HIROSHI YAMAGUCHI, HIROSHI OHNUMA, MASAHIKO IGARASHI*, \\ MAKOTO TOMINAGA* AND TAKEO KATO \\ Third Department of Internal Medicine, Yamagata University School of Medicine, Yamagata 990-9585, Japan \\ *Department of Laboratory Medicine, Yamagata University School of Medicine, Yamagata 990-9585, Japan
}

\begin{abstract}
The association of the ACE gene I/D polymorphism with type 2 diabetes (DM) was examined in a populationbased Japanese sample. A total of 902 individuals (490 females and 412 males, age $58.8 \pm 12.2 \mathrm{yr}$ ) from a cohort population $(n=3,706)$ of the Funagata diabetes study were divided into three groups according to genotype: D/D $(\mathrm{n}=104), \mathrm{I} / \mathrm{D}(\mathrm{n}=436)$ and $\mathrm{I} / \mathrm{I}(\mathrm{n}=362)$. Chi-square test and ANOVA were used for association studies and to assess the differences in the traits' values, respectively. More individuals with the genotypes $\mathrm{D} / \mathrm{D}$ and $\mathrm{I} / \mathrm{D}$ were diabetic $(8.7 \%$ and $4.1 \%$, respectively) than those with the genotype I/I $(2.8 \%, \mathrm{p}=0.008$ and $\mathrm{p}=0.032$, respectively). The genotype $\mathrm{D} / \mathrm{D}$ was a risk factor for DM (relative risk (RR) 3.13, 95\% CI 1.31-7.51), and also for DM and IGT (RR 1.78, 95\% CI 1.14-2.76). Multiple logistic regression analysis also showed that the genotypes with the D allele were risk factors for DM and IGT even when adjusting for age, sex, hypertension and serum total cholesterol levels (odds ratio 1.49, 95\% CI 1.01-2.21). The D allele of the ACE gene I/D polymorphism is a risk factor for DM.
\end{abstract}

Key words: ACE, I/D polymorphism, Diabetes, Population-based study, Relative risk

(Endocrine Journal 50: 393-398, 2003)

THE angiotensin-converting enzyme (ACE) plays an important role in the renin-angiotensin system, by generating vasoconstrictor angiotensin II and degrading vasodilator kinins [1]. Changes of serum ACE levels thus seem influence the renin-angiotensin system, which consists of endocrine (or circulating) and local systems. A commonly occurring 287-bp insertion (I)/ deletion (D) polymorphism in intron 16 of the ACE gene accounts for a large portion of the variance in serum ACE levels [2]. Subjects with the genotype D/D displayed the highest mean levels of serum ACE, those with the genotype I/I displayed the lowest, and those with the genotype I/D displayed intermediate levels.

Received: December 9, 2002

Accepted: April 8, 2003

Correspondence to: Makoto DAIMON, M.D., Ph.D., Third Department of Internal Medicine, Yamagata University School of Medicine, 2-2-2 Iida-Nishi, Yamagata 990-9585, Japan
Therefore, this ACE gene polymorphism has been expected to be associated with various diseases related to the renin-angiotensin system. Indeed, the D allele of the polymorphism has been reported to be associated with diseases that influenced by the endocrine system, such as diabetic nephropathy [3-9], coronary artery disease [8, 10-12], arterial wall thickness [13], arterial stiffness [14] and hypertension [11, 15].

In addition to the endocrine system, local systems exist in many tissues including skeletal muscle [16] and adipose tissue [17]. The local skeletal-muscle renin-angiotensin systems may modify the use of substrate through a kallikrein-kinin system, where low ACE (namely, kininase II) activity leads to an increased glucose uptake during exercise [18]. Furthermore, low ACE activity (ACE-inhibition) has been reported to increase skeletal-muscle glucose uptake, insulin sensitivity, glycogen storage, glucose transporter GLUT-4 synthase activity and hexokinase activ- 
ity [19]. The local adipose renin-angiotensin systems may alter substrate mobilization from fat stores. Low ACE activity has been reported to increase insulinstimulated hexone transport in adipocytes [20] and insulin suppression of non-esterified fatty-acid flux [21]. Taken together, these findings seem to indicate that low ACE activity is advantageous for glucose metabolism. Inversely, high ACE activity, namely the ACE genotype $\mathrm{D} / \mathrm{D}$, seems to be disadvantageous for glucose metabolism or to be a risk factor for impaired glucose metabolism or DM. Therefore, we examined the association of the ACE gene I/D polymorphism with DM in a large population-based Japanese sample.

\section{Materials and Methods}

\section{Subjects}

The Funagata diabetes study is a population-based study to clarify the risk factors, related conditions, and consequences for DM from an epidemiological point of view [22]. In Funagata, an agricultural area located about $400 \mathrm{~km}$ north of Tokyo, the population aged over 35 years was 4,183 in 1995 . Individuals $(\mathrm{n}=377)$ with cerebrovascular diseases or other disabilities who were unable to attend the study were excluded. One hundred residents who had been identified by public health nurses and through contacts with outpatient clinics as having medication for diabetes were also excluded. Therefore, the number of residents registered for the study was 3,706. From 1995 to 1997, 2,013 residents attended the study. Among them, 902 were enrolled for a genetic analysis for the ACE I/D polymorphism; the participation rate for this genetic analysis was $44.8 \%$. This study was approved by the Ethical Committee of the Yamagata University School of Medicine. Written informed consent to participate in this study was obtained from the subjects involved. The mean age $( \pm \mathrm{SD})$ and the sex ratio (female/male) of the study group were $58.8 \pm 12.2$ and $490 / 412$, respectively. Glucose tolerance was diagnosed according to the 1985 WHO criteria [23]. The numbers of individuals with normal glucose tolerance (NGT), impaired glucose tolerance (IGT) and DM were 750,115 and 37 , respectively.

\section{Clinical traits examined}

Along with the genetic analysis, the following traits were analyzed: height, body weight, 75-g oral glucose tolerance test (OGTT), HbAlc, waist circumference, hip circumference, waist-to-hip ratio, body mass index (BMI), percent body fat, systolic blood pressure, diastolic blood pressure, total serum cholesterol, serum triglyceride, and serum HDL cholesterol. Percent body fat was assessed based on the principles of bioelectrical impedance [24]. Hypertension was diagnosed if the subjects had a systolic blood pressure of $\geq 160 \mathrm{mmHg}$ or a diastolic blood pressure of $\geq 95 \mathrm{mmHg}$ or was undergoing medical treatment for hypertension.

\section{Genetic analysis}

Genomic DNA was isolated from peripheral blood leukocytes by proteinase $\mathrm{K}$ and the phenol/chloroform extraction procedure. The genotyping for the ACE I/D polymorphism was performed by polymerase chain reaction-restriction fragment length polymorphism analysis as previously described [25]. The study population was divided into three groups according to genotype: $\mathrm{D} / \mathrm{D}(\mathrm{n}=104), \mathrm{I} / \mathrm{D}(\mathrm{n}=436)$ and $\mathrm{I} / \mathrm{I}(\mathrm{n}=362)$. Mean age $( \pm \mathrm{SD})$ and sex ratio (female/male) of the groups $(\mathrm{D} / \mathrm{D}, \mathrm{I} / \mathrm{D}$ and $\mathrm{I} / \mathrm{I})$ were $58.3 \pm 12.1$ and $59 / 45$, $58.8 \pm 12.4$ and $233 / 203$, and $57.4 \pm 11.9$ and $198 / 164$, respectively. No statistical differences in age or sex ratio were observed among the groups.

\section{Statistic analysis}

Chi-square tests were performed for the association studies. Data are given as the means \pm SD. The statistical significances of the differences of the trait values between two groups (D/D vs. I/I or I/D vs. I/I) were assessed by analysis of variance (ANOVA). Scheffe's F test was used for post hoc analysis. Scheffe's F test generates confidence intervals (CIs) that are quite wide, and thus has less statistical power to detect differences than do the other post hoc tests. Therefore, the Scheffe's F test is considered to be suitable to make elaborate comparisons, or to calculate contrast. Multiple logistic regression analysis was used to determine the independent association of the genotypes with the $\mathrm{D}$ allele (namely, genotypes $\mathrm{D} / \mathrm{D}$ and $\mathrm{I} / \mathrm{D}$ ), age, sex, hypertension and serum total cholesterol 
levels with DM or DM and IGT. For this analysis, the number of DM patients did not seem to be large enough. Therefore, DM and IGT were treated together for the analysis. A value of $p<0.05$ was accepted as statistically significant.

\section{Results}

The distribution of the genotypes defined by the ACE I/D polymorphism was examined. The frequencies of the D and I alleles were $35.7 \%$ and $64.3 \%$, respectively, and the frequencies of the genotypes $\mathrm{D} / \mathrm{D}$, I/D and I/I were $11.5 \%, 48.3 \%$ and $40.1 \%$, respectively. The genotypes were found to be in Hardy-Weinberg equilibrium. Allelic and genotype frequencies were in concordance with other observations in Japan $(3,4,9,10)$; therefore, our study population seemed to be genetically similar to others reported in Japan.

The associations of the genotype with DM is shown in Table 1. More individuals with the genotypes $\mathrm{D} / \mathrm{D}$ $(8.7 \%, \mathrm{p}=0.008)$ and $\mathrm{I} / \mathrm{D}(4.1 \%, \mathrm{p}=0.032)$ were diabetic than those with the genotype I/I $(2.8 \%)$. There were no differences between the genotypes $\mathrm{D} / \mathrm{D}$ and $\mathrm{I} / \mathrm{D}$ in terms of the frequencies of diabetic individuals $(p=0.235)$. The genotypes $D / D$ and ID were associated with DM. Relative risk (RR) of the genotypes for DM, or DM and IGT can be estimated here, since this is a population-based study, or cross-sectional study. The RRs of the genotypes with the D allele (namely, the genotypes $\mathrm{D} / \mathrm{D}$ and $\mathrm{D} / \mathrm{I}), \mathrm{D} / \mathrm{D}$ and $\mathrm{D} / \mathrm{I}$ for $\mathrm{DM}$ were 1.81 (95\% CI $0.89-3.69), 3.13$ (95\% CI 1.31-7.51) and 1.49 (95\% CI 0.70-3.20), respectively. However, multiple logistic regression analysis to reveal the independent association of the genotypes with the $\mathrm{D}$ allele, BMI, sex, hypertension and serum total cholesterol

Table 1. Frequency of DM and the ACE gene I/D polymorphism

\begin{tabular}{lrrr}
\hline & \multicolumn{3}{c}{ Genotypes } \\
\cline { 2 - 4 } & \multicolumn{1}{c}{$\mathrm{D} / \mathrm{D}^{*}$} & \multicolumn{1}{c}{$\mathrm{I} / \mathrm{D}^{*}$} & \multicolumn{1}{c}{$\mathrm{I} / \mathrm{I}$} \\
\hline DM & $9(8.7)$ & $18(4.1)$ & $10(2.8)$ \\
IGT & $15(14.4)$ & $63(14.4)$ & $37(10.2)$ \\
NGT & $80(76.9)$ & $355(81.4)$ & $315(87.0)$ \\
\hline
\end{tabular}

Data are $\mathrm{N}(\%)$. * indicates statistical significance

Frequency of DM in the genotype D/D and I/D were significantly different from that in the genotype $\mathrm{I} / \mathrm{I}(\mathrm{p}=0.008$ and 0.032 , respectively) levels with DM did not show a significant association of the genotypes (odds ratio (OR): $1.75(95 \% \mathrm{CI}$ : $0.820-3.723), \mathrm{p}=0.148 ; \mathrm{R}^{2}$ of the test, 0.096). We speculated that the number of DM patients in this study was not large enough to provide a statistical power that was strong enough to detect the association. Therefore, we treated DM and IGT together to enlarge the case number and calculated the RRs of the genotypes for DM and IGT. We believe the genetic background of IGT to be similar to that of DM, although the extent of metabolic abnormalities is different between DM and IGT. The RRs of the genotypes with the $\mathrm{D}$ allele, $\mathrm{D} / \mathrm{D}$ and $\mathrm{D} / \mathrm{I}$ for $\mathrm{DM}$ and IGT were 1.50 (95\% CI 1.09-2.06), 1.78 (95\% CI 1.14-2.76) and 1.43 (95\% CI 1.03-1.99), respectively. Furthermore, multiple logistic regression analysis to reveal the independent association with DM and IGT also showed the significant associations of the genotypes with the D allele, age (1 year), BMI $\left(1 \mathrm{~kg} / \mathrm{m}^{2}\right)$ and serum total cholesterol $(10 \mathrm{mg} / \mathrm{dl})\left(\mathrm{R}^{2}\right.$ of the test, 0.115$)$ (Table 2). No significant association was found for sex or hypertension (Table 2). These results indicate that the $\mathrm{D}$ allele of the polymorphism is an independent risk factor for DM or for DM and IGT.

As described in material and methods, the traits related to diabetes, obesity, hypertension and dyslipidemia were measured. Individuals with the genotype D/D had higher 2-hr plasma glucose levels $(122.0 \pm 58.7$ vs. $106.8 \pm 34.4, \mathrm{p}=0.005)$ than those with the genotype I/I (Table 3). The two groups showed no significant differences in the other traits examined (Table 3). No trait was different between the individuals with the genotypes I/D and I/I, although the 2-hr plasma glucose levels tended to be higher in the individuals with the genotype I/D than in those with the genotype I/I $(113.6 \pm 42.5$ vs. $106.8 \pm 34.4$, $\mathrm{p}=0.073)$. Namely, the traits related to obesity, insu-

Table 2. Risk factors for DM and IGT when adjusting for clinical traits by multiple logistic regression analysis

\begin{tabular}{lrrr}
\hline \multicolumn{1}{c}{ Variables } & odds ratio & $95 \%$ CI & \multicolumn{1}{c}{$\mathrm{p}$} \\
\hline ACE I/D polymorphism (D allele) & 1.49 & $1.01-2.21$ & 0.044 \\
Age (1 year) & 1.07 & $1.05-1.09$ & $<0.001$ \\
Sex (Female) & 0.73 & $0.50-1.06$ & 0.099 \\
BMI $\left(1 \mathrm{~kg} / \mathrm{m}^{2}\right)$ & 1.11 & $1.04-1.18$ & 0.001 \\
Hypertension & 1.37 & $0.92-2.04$ & 0.123 \\
Serum total cholesterol $(10 \mathrm{mg} / \mathrm{dl})$ & 1.07 & $1.01-1.13$ & 0.023 \\
\hline
\end{tabular}

$\mathrm{CI}$ indicates confidence interval. 
Table 3. Effect of ACE gene I/D polymorphism

\begin{tabular}{|c|c|c|c|c|c|}
\hline \multirow[b]{3}{*}{ Parameter } & \multicolumn{5}{|c|}{ Genotypes } \\
\hline & \multicolumn{2}{|c|}{$\mathrm{D} / \mathrm{D}$} & \multicolumn{2}{|c|}{$\mathrm{I} / \mathrm{D}$} & \multirow{2}{*}{$\begin{array}{c}\mathrm{I} / \mathrm{I} \\
\text { Value }\end{array}$} \\
\hline & Value & $\mathrm{P}$ & Value & $\mathrm{P}$ & \\
\hline Gender (W/M) & $59 / 45$ & & $233 / 203$ & & $198 / 164$ \\
\hline Age (yr) & $58.3 \pm 12.1$ & 0.797 & $58.8 \pm 12.4$ & 0.312 & $57.4 \pm 11.9$ \\
\hline Height (cm) & $155.8 \pm 8.9$ & 0.997 & $155.6 \pm 8.7$ & 0.912 & $155.8 \pm 9.1$ \\
\hline Body weight (kg) & $58.5 \pm 10.1$ & 0.615 & $57.1 \pm 9.7$ & 0.847 & $57.5 \pm 10.2$ \\
\hline Fasting plasma glucose (mg/dl) & $95.9 \pm 14.2$ & 0.236 & $95.4 \pm 12.3$ & 0.107 & $93.6 \pm 11.5$ \\
\hline $2 \mathrm{hr}$ plasma glucose $(\mathrm{mg} / \mathrm{dl})$ & $122.0 \pm 58.7$ & $0.005^{*}$ & $113.6 \pm 42.5$ & 0.073 & $106.8 \pm 34.4$ \\
\hline Fasting serum insulin $(\mathrm{mU} / \mathrm{ml})$ & $4.87 \pm 3.26$ & 0.792 & $4.91 \pm 4.03$ & 0.482 & $4.61 \pm 2.88$ \\
\hline $\operatorname{HbA1c}(\%)$ & $5.51 \pm 0.62$ & 0.161 & $5.45 \pm 0.54$ & 0.359 & $5.40 \pm 0.44$ \\
\hline Waist circumference $(\mathrm{cm})$ & $79.6 \pm 9.02$ & 0.575 & $78.6 \pm 8.85$ & 0.997 & $78.6 \pm 8.91$ \\
\hline Hip circumference $(\mathrm{cm})$ & $92.6 \pm 5.96$ & 0.843 & $91.8 \pm 5.71$ & 0.671 & $92.2 \pm 5.91$ \\
\hline Waist to hip ratio & $0.860 \pm 0.074$ & 0.594 & $0.855 \pm 0.071$ & 0.838 & $0.852 \pm 0.070$ \\
\hline Body mass index $\left(\mathrm{kg} / \mathrm{m}^{2}\right)$ & $24.05 \pm 3.03$ & 0.394 & $23.52 \pm 3.09$ & 0.967 & $23.58 \pm 3.11$ \\
\hline Percent body fat (\%) & $27.07 \pm 6.44$ & 0.399 & $25.79 \pm 6.83$ & 0.862 & $26.05 \pm 6.73$ \\
\hline Systolic blood pressure $(\mathrm{mmHg})$ & $128.8 \pm 16.2$ & 0.151 & $126.4 \pm 18.0$ & 0.575 & $125.1 \pm 16.8$ \\
\hline Diastolic blood pressure (mmHg) & $74.9 \pm 9.20$ & 0.962 & $74.7 \pm 9.85$ & 0.990 & $74.6 \pm 10.0$ \\
\hline Total cholesterol (mg/dl) & $210.8 \pm 34.9$ & 0.826 & $205.3 \pm 35.7$ & 0.465 & $208.4 \pm 34.8$ \\
\hline Trigliyceride (mg/dl) & $137.7 \pm 177.2$ & 0.192 & $111.5 \pm 80.3$ & 0.765 & $116.9 \pm 97.6$ \\
\hline HDL cholesterol (mg/dl) & $57.6 \pm 14.1$ & 0.732 & $57.3 \pm 14.2$ & 0.280 & $58.9 \pm 15.1$ \\
\hline HOMA-IR & $1.16 \pm 0.81$ & 0.742 & $1.19 \pm 1.06$ & 0.287 & $1.08 \pm 0.74$ \\
\hline
\end{tabular}

Values are mean $\pm \mathrm{SD}$. P values compared subjects carrying D/D or I/D genotype with subjects carrying I/I genotype.

lin resistance, hypertension or dyslipidemia were not different among the groups.

\section{Discussion}

The genotypes $\mathrm{D} / \mathrm{D}$ and $\mathrm{I} / \mathrm{D}$ were significantly associated with DM. The associations of these genotypes with DM complications or DM-related conditions have been reported in many case-control studies [3-10]. However, an association of the genotype with DM per se has not been clearly shown so far. In the present study, we determined the association of the genotype with DM. The relatively large number of our subjects (902 individuals) and the fact that our subjects were from a community (namely, no stratification was expected in the study population) was expected to increase the power to reveal the association. Furthermore, multiple logistic regression analysis revealed that the genotypes with the D allele were risk factors for DM and IGT independently from age, sex, BMI and other clinical traits. The genotype D/D seemed to be a stronger risk factor than the genotype I/D (RR: 1.78 vs 1.43$)$. These findings indicated that the $\mathrm{D}$ allele of the polymorphism was a risk factor for DM, and that the D allele contributed to the pathogenesis of DM in a dosage dependent manner.

We conjectured that the increased ACE activity in the individuals with the $\mathrm{D}$ allele may lead to impaired glucose metabolism or insulin resistance and eventually to DM. However, we could not find any evidence to support this idea in this study. The traits related to insulin resistance such as fasting serum insulin levels and HOMA-IR, were not significantly different among the individuals with the genotypes $\mathrm{D} / \mathrm{D}, \mathrm{I} / \mathrm{D}$, and $\mathrm{I} / \mathrm{I}$. Thus, at this point the mechanisms involved in the association of the $\mathrm{D}$ allele with the increased prevalence of DM are not clear. The increased ACE activity in the local renin-angiotensin system might be more responsible for the association than that in the systemic renin-angiotensin system. Thus, the traits related to the systemic renin-angiotensin system, or the serum levels of ACE, might not be clearly different among the study groups. It seems also possible that the traits used here such as fasting serum insulin levels and HOMA-IR were not appropriate to distinguish the differences in insulin resistance among the groups, since Japanese seem to more prone to become incompetent 
at secreting insulin to overcome existing insulin resistance. The number of the individuals with the genotype D/D (11.5\%) might not be large enough to reveal the differences in the traits as significant. In addition, it should be noted that the ACE I/D polymorphism may not be the causative variation but rather merely the genetic marker that is in linkage disequilibrium with other causative variations. Indeed, Rieder et al. found 78 variations of the gene, 17 of which were in absolute linkage disequilibrium with the I/D polymorphism reported here [26]. Therefore, some of these 17 variations may be causative. If so, an association study with such gene variations may reveal the association of the gene with DM to be even more significant.
The association of the D allele with the increased prevalence of DM was found in a dosage dependent manner in this study. This result seemed to be in good agreement with the findings of the association of the administration of an ACE inhibitor (namely, the decrease of ACE activity) with lower rates of new diagnosis (or the incidence) of DM in high-risk individuals $[27,28]$. The $\mathrm{D}$ allele, which is responsible for increased ACE activity, seemed to be responsible for the increase prevalence of DM.

In conclusion, the D allele of the ACE gene I/D polymorphism was shown to be associated with DM in a population-based Japanese sample.

\section{References}

1. Costerousse O, Danilov S, Alhenc-Gelas F (1997) Genetics of angiotensin I-converting enzyme. Clin Exp Hypertens 19: 659-669.

2. Rigat B, Hubert C, Alhenc-Gelas F, Cambien F, Corvol P, Soubrier F (1990) An insertion/deletion polymorphism in the angiotensin I-converting enzyme gene accounting for half the variance of serum enzyme levels. J Clin Invest 86: 1343-1346.

3. Nakajima S, Baba T, Yajima Y (1996) Is ACE gene polymorphism a useful marker for diabetic alubuminuria in Japanese NIDDM patients? Diabetes Care 19: $1420-1422$.

4. Ohno T, Kawazu S, Tomono S (1996) Association analysis of the polymorphisms of angiotensin-converting enzyme and angiotensinogen genes with diabetic nephropathy in Japanese non-insulin-dependent diabetes. Metabolism 45: 218-222.

5. Marre M, Bernadet P, Gallois Y, Savagner F, Guyene TT, Hallab M, Cambien F, Passa P, Alhenc-Gelas F (1994) Relationship between angiotensin I converting enzyme gene polymorphism, plasma levels, and diabetic retinal and renal complications. Diabetes 43: 384-388.

6. Kunz R, Bork JP, Fritsche L, Ringel J, Sharma AM (1998) Association between the angiotensin-converting enzyme-insertion/deletion polymorphism and diabetic nephropathy: a methodologic appraisal and systemic review. J Am Soc Nephrol 9: 1653-1663.

7. Dudley CRK, Keavney B, Stratton IM, Turner RC, Ratcliffe PJ (1995) UK prospective diabetes study XV: relationship of renin-anigiotensin system gene polymorphism with microalubuminuria in NIDDM. Kidney Int 48: 1907-1911.

8. Kennon B, Petrie JR, Small M, Connell JMC (1999) Angiotensin-converting enzyme gene and diabetes mellitus. Diabet Med 16: 448-458.

9. Jeffers BW, Estacio RO, Raynolds MV, Schrier RW (1997) Angiotensin-converting enzyme gene polymorphism in non-insulin dependent diabetes mellitus and its relationship with diabetic nephropathy. Kidney Int 52: 473-477.

10. Cambien F, Poirier O, Lecerf L, Evance A, Cambou JP, Arveiler D, Luc G, Bard JM, Bara L, Ricard S, Tiret L, Amouyel P, Alhenc-Gelas F, Soubrier F (1992) Deletion polymorphism in the gene for angiotensin-converting enzyme is a potent risk factor for myocardial infarction. Nature 359: 641-644.

11. Ruiz J, Blanché H, Cohen N, Velho G, Cambien F, Cohen D, Passa P, Froguel P (1994) Insertion/deletion polymorphism of the angiotensin-converting enzyme gene is strongly associated with coronary heart disease in non-insulin-dependent diabetes mellitus. Proc Natl Acad Sci USA 91: 3662-2665.

12. Fujisawa T, Ikegami H, Shen GQ, Yamato E, Takekawa K, Nakagawa Y, Hamada Y, Ueda H, Rakugi H, Higaki J (1995) AngiotensinI-converting enzyme gene polymorphism is associated with myocardial infarction, but not with retinopathy or nephropathy, in NIDDM. Diabetes Care 18: 983-985.

13. Kogawa K, Nishizawa Y, Hosoi M, Kawagishi T, Maekawa K, Shoji T, Okuno Y, Morii H (1997) Effect of polymorphism of apolipoprotein $\mathrm{E}$ and angiotensionconverting enzymes genes on arterial wall thickness. Diabetes 46: 682-687.

14. Taniwaki H, Kawagishi T, Emoto M, Shoji T, Hosoi M, Kogawa K, Nishizawa Y, Morii H (1999) Association of ACE gene polymorphism with arterial stiffness in patients with type 2 diabetes. Diabetes Care 22: 1858-1864.

15. Bengtsson K, Orho-Melander M, Lindblad U, Melander 
O, Bog-Hansen E, Ranstam J, Groop L (1999) Polymorphism in the angiotensin converting enzyme but not in the angiotensinogen gene is associated with hypertension and type 2 diabetes: the Skaraborg hypertention and diabetes project. J Hypertens 17: 1569-1575.

16. Dragovic T, Minshall R, Jackman HL, Wang LX, Erdos EG (1996) Kininase II-type enzymes; their putative role in muscle energy metabolism. Diabetes 45 : S34-S37.

17. Jonsson JR, Game PA, Head RJ, Frewin DB (1994) The expression and localization of the angiotensinconverting enzyme mRNA in human adipose tissue. Blood Press 3: 72-75.

18. Dietze G, Wicklmayr M, Bottger I, Schifmann R, Geiger R, Fritz H, Mehnert H (1980) The kallikreinkinin system and muscle metabolism: biochemical aspects. Agents Actions 10: 334-343.

19. Henriksen EJ, Jacob S (1995) Effect of captopril on glucose transport activity in skeletal muscle of obese Zuker rats. Metabolism 44: 267-272.

20. Goldman J, Pfister D, Vukmirovich R (1987) Potentiation of insulin stimulation of hexose transport by kallikrein and bradykinin in isolated rat adipocytes. Mol Cell Endocrinol 50: 183-191.

21. Hennes MM, O’Shaughnessy IM, Kelly TM, LaBelle P, Egan BM, Kissebah AH (1996) Insulin-resistant lipolysis in abdominally obese hypertensive individuals: role of the renin-angiotensin system. Hypertension 28: 120-126.

22. Oizumi T, Daimon M, Saitoh T, Kameda W, Yamaguchi $\mathrm{H}$, Ohnuma H, Igarashi M, Eguchi H, Manaka H,
Tominaga M, Kato T (2001) Genotype Arg/Arg, but not Trp/Arg, of the Trp64Arg polymorphism of the b3adrenergic receptor is associated with type 2 diabetes and obesity in a large Japanese sample. Diabetes Care 24: 1579-1583.

23. World Health Organization: Diabetes mellitus. Geneva, World Health Org., 1985 (Tech. Report. Ser. No. 727)

24. Jebb SA, Cole TJ, Doman D, Murgatroyd PR, Prentice AM (2000) Evaluation of the novel Tanita body-fat analyser to measure body composition by comparison with a four-compartment model. Br J Nutr 83: 115122.

25. Lindpaintner K, Pfeffer MA, Kreutz R, Stampfer MJ, Grodstein F, LaMotte F, Buring J, Hennekens CH (1995) A prospective evaluation of an angiotensinconverting-enzyme gene polymorphism and the risk of ischemic heart disease. New Engl J Med 332: 706-711.

26. Rieder MJ, Taylor SL, Clark AG, Nickerson DA (1999) Sequence variation in the human angiotensin converting enzyme. Nature Genet 22: 59-62.

27. Hammsom L, Lindholm LH, Niskanen L, Lanke J, Hedner T, Niklason A, Luomanmäki K, Dahlöf B, de Faire U, Mörlin C, Karlberg BE, Wester PO, Björck JE (1999) Effect of angiotensin-converting-enzyme inhibition compared with conventional therapy on cardiovascular morbidity and mortality in hypertension: the captoril prevention project (CAPPP) randomised trial. Lancet 353: 611-616.

28. Yusuf S, Gerstein H, Hoogwerf B, Pogue J, Bosch J, Wolffenbuttel BHR, Zinman B (2001) Ramipril and the development of diabetes. JAMA 286: 1882-1885. 